\title{
Eating Disorders and Reproduction in Women
}

\author{
Bayramova $\mathrm{AN}^{*}$ \\ Department of Gynecology, Russia
}

Submission: April 05, 2017; Published: June 05, 2017

*Corresponding author: Bayramova AN, Department of Gynecology, Russia, Tel: +79610220184; Email: afa.bayramova@yandex.ru

\begin{abstract}
Malnutrition is a major problem in developing countries, and obesity and eating disorders are increasingly common in developing as well as developed countries. The reproductive axis is closely linked to nutritional status, especially under nutrition in the female, and inhibitory pathways involving detectors in the hind brain suppress ovulation in subjects with weight loss. Recovery may occur after minimal reacquisition of weight because energy balance is more important than body fat mass. Anorexia nervosa and bulimia nervosa affect up to $5 \%$ of women of reproductive age causing amenorrhoea, infertility and, in those who do conceive, an increased likelihood of miscarriage.
\end{abstract}

Keywords: Contraception; Miscarriage; Nutrition; Obesity; Reproduction

\section{Introduction}

Nutrition problems are strikingly different in developing nations (deprivation and under nutrition) and developed nations (eating disorders and obesity), although obesity is on the increase even in developing countries. Malnutrition is associated with $55 \%$ of deaths among children under the age of five. Over 4 million of the 12 million annual deaths are in sub-Saharan Africa alone, where every third child is underweight and two out of five are stunted. Iron deficiency anaemia is a contributing factor in over $20 \%$ of post-birth maternal deaths in Africa and Asia. Nearly 67 million children are wasted (weigh less than they should for their height); and about 183 million weigh less than they should for their age. Unfortunately, reducing poverty and increasing food production by themselves cannot solve the nutrition problems of the poor in developing countries [1]. Major public health and social expenditures are needed to address these devastating conditions that at present cannot be remedied substantially by medical practice.

In contrast, developed nations experience little deprivation, but eating disorders and obesity are increasingly common and may be amenable to medical intervention. For females, reproduction involves much greater energy expenditure than for males, and as a protective mechanism against under nutrition, the reproductive axis is closely linked to nutritional status. As one consequence, eating disorders leading to loss of weight are associated with reduced frequency or cessation of ovulation. Since energy balance more than absolute weight loss is the key factor, there may be a return of ovulation after no more than a small percentage change in body weight recovery. Obesity, however, is a less reliable risk factor of infertility except among obese women who also have polycystic ovarian disease. This review of nutrition and reproduction will address the clinical conditions that are associated with underweight in developed countries. It will outline the physiological mechanisms and clinical conditions associated with under nutrition.

\section{Under Nutrition}

\section{Physiological mechanisms}

The reproductive system is extremely sensitive to influences from the external environment [2]. Most animals adjust their pattern of reproduction so that the chances of their offspring surviving are maximal. A common strategy involves timing of conception by photoperiod and/or rainfall which usually ensures that birth takes place in a season when food and climatic conditions are favorable, such as spring.

Reproduction involves much greater energy expenditure in the female than in the male. The nourishing of the offspring during pregnancy and lactation and their subsequent rearing to adulthood are the biggest expenditure of energy that a female mammal will make in her lifetime. Hence, the female reproductive system is much more sensitive to disruption than the male.

Because reproduction involves energy expenditure, it is sensible that the physiological control mechanisms are linked to those involved with appetite and nutrition [3]. Food is used as a source of energy for a variety of essential and non- 
essential functions. In times of deprivation it is necessary to ration available oxidizable substrate in favour of those essential functions involved in staying alive, e.g. keeping warm [4]. Reproduction is expendable at least in the short term and can be deferred until times are more favorable. During lean times animals have devised a number of strategies to reduce energy output such as huddling together in insulated nests (houses), daily torpor or hibernation. Very little energy is diverted to storage of fat. Rather, calories are mobilized from fat stores in an attempt to maintain energy balance. Thus, it is energy balance not fatness per se that regulates reproductive function.

\section{Energy balance and ovulation}

Approximately $1-5 \%$ of women suffer from 'weight-related amenorrhoea' [5]. Because many girls with delayed puberty are relatively thin during adolescence it has been suggested that a certain critical body weight $(47 \mathrm{~kg})$ or body fat content is required for onset of cyclical ovarian activity [6,7]. However, although ovarian activity and fat content are correlated they are not causally linked. It is relatively easy to dissociate fatness and reproductive function. Thus, for example, menstrual cycles return in some female athletes when energy expenditure is reduced such as after an injury long before there is any change in body weight or an increase in body fat [8].

Reproductive function, like appetite, is responsive to shortterm changes in metabolic food oxidation. For example, many breeds of sheep are capable of altering their ovulation rate and hence the number of lambs they carry depending on body condition (Martin et al., 2004). Feeding underweight sheep highcalorie supplement of lupins or clover hastens the onset of the breeding season ('flushing') and increases the ovulation rate. A similar effect can be produced by administration of a glucogenic 'drench' [9].

The mechanisms involved in this adjustment of reproductive function involve the availability of calories. When Syrian hamsters are administered 2 de-oxy-d-glucose (DG), which limits glucose oxidation, ovulatory cycles are interrupted rapidly (Schneider and Wade, 1990). It is likely that this involves both central and peripheral mechanisms. In sheep and rats infusion of DG directly into the lateral ventricles depressed LH secretion $[10,11]$. Subsequent experimentation has helped define the pathway by which calorie deprivation leads to short-term inhibition of reproductive function. It appears that in the rat the metabolic signals are detected by chemo receptors in an area of the hind brain area (postrema (PA)). The signals involved in this are not entirely clear but probably include leptin and insulin/ glucose $[12,13]$.

Epinephrine, nor-epinephrine and neuropeptide Y (NPY) neurones connect to the forebrain to influence GnRH secretion in the hypothalamus [14]. When the animal is replete, the system is free running. The 'brake' is only applied during times of negative energy balance and involves NPY neurons [14,15]. Nutrition and reproduction [3]. NE, nor-epinephrine; NPY, neuropeptide Y; PA, postrema.

Recent observations in women with 'hypothalamic amenorrhoea' have suggested that these experimental studies are relevant to clinical disorders. Women with anovulation associated with strenuous exercise or who are underweight, have low levels of leptin, LH and estradiol [16]. The frequency of gonadotropin pulses is too low to sustain development of antral follicles to the point of ovulation. When leptin was injected to restore levels to normal, there was an immediate increase in the frequency of LH pulses within 2 weeks, followed by growth of large ovarian follicles. Ovulatory cycles were restored in three out of eight women. Whether leptin acts directly on the hypothalamus or increases the availability of oxidizable metabolic substrates or both is unknown. It is likely that leptin plays a significant role in mediating this event although it should be noted that when nutritionally starved animals are refed the frequency of LH pulses increases long before there is an increase in circulating leptin [17].

\section{Energy balance and implantation}

Nutrition not only influences ovulation and fertilization but also implantation and early fetal development. Paradoxically overfeeding of sheep in the first few weeks of pregnancy results in an increase in embryonic mortality associated with low levels of progesterone [18]. The level of nutrition during pregnancy has a profound effect on fetal development and subsequent susceptibility in adulthood to disease. When ewes were underfed during mid pregnancy there was an increase in the incidence of pre-term birth [19]. The concept of fetal programming in utero which was originally derived from epidemiological studies in man has been confirmed in a number of experimental studies in animals $[20,21]$. Thus there is little doubt that nutrition plays an important role during pregnancy as well as in determining the timing and quality of reproductive activity.

\section{Eating disorders}

Under nutrition implies inadequate food intake or faulty assimilation due to low-caloric intake or limited nutritional diversity. In developed countries it is most commonly found in women with eating disorders.

Although records of under nutrition from developing countries are scarce, the experience from the Dutch famine in 1944-1945 is relevant to modern countries with a high prevalence of malnutrition. In the Western Netherlands, average daily intake fell from 1500 to less than 700 kilocalories from October 1944 to January 1945 and the birth rate fell 9 months after October 1944. Future reproductive life was affected among women who were severely affected by famine at 3 to 13 years of age: they had a 1.9 fold higher risk $(95 \% \mathrm{CI}=.31 .8)$ of having fewer than the desired number of children in their lifetime [22]. 
Under nutrition due to eating disorders may affect ovulation and fertility, alter the response to conventional treatment and assisted reproduction technology for infertility and have effects on pregnancy and the newborn.

The relevant eating disorders are bulimia nervosa (excessive eating and compensatory activities such as vomiting or laxative abuse) and anorexia nervosa (low body mass index (BMI) and fear of weight gain]. Both commonly onset in adolescence and occur in $3 \%$ of young women [23].

Milder eating disorders (not otherwise specified) occur in a further $3-5 \%$ of women [24]. Anorexia nervosa (1\% of young women) is defined as body weight less than $85 \%$ of expected weight or BMI less than $17.5 \mathrm{~kg} / \mathrm{m} 2$, coupled with intense fear of weight gain and an inaccurate perception of body image. Bulimia nervosa (1า-5\% of young women) involves recurrent binge eating, compensated by recurrent purging, excessive exercise or fasting, excessive concern about body weight or shape and the absence of anorexia nervosa [20]. Full recovery with bulimia nervosa is more likely (74\%) than with anorexia nervosa (33\%), but to achieve these recovery rates required a median of 90 months of follow-up with treatment and relapses occurred in about one third of full recoveries [25].

\section{Effects on fertility}

Menstrual periods often cease after a $10-15 \%$ decrease in normal body weight. In theory the mechanisms include altered regulation of gonadotropin-releasing hormone secretion and changes in the dopaminergic and opioid systems. Amenorrhoea occurs in $15-30 \%$ of women with anorexia nervosa $[26,27]$. Amenorrhoea is also a component of the female athletic triad, along with osteoporosis and milder versions of the eating disorders [28]. Oligoamenorrhoea may occur with bulimia nervosa even in women with BMI in the normal range. The amenorrhoea persisted in $30 \%$ of patients who had regained their normal weight during recovery from anorexia nervosa with amenorrhoea [29].

With respect to fertility, anorexia nervosa or bulimia nervosa was present in 5 (8\%) of 66 consecutive infertility clinic patients; non-specified eating disorders were found in a further six (9\%) [24]. Seven of the 11 women with eating disorders were among the 12 of 66 with oligoanovulation; thus, in this small group, eating disorders were present in about $60 \%$ of women with oligoanovulation. Although women with anovulation are unlikely to conceive, fertility may be normal in later years among women who achieve normal weight after recovery from eating disorders [28,30]. Women with a history of anorexia nervosa and community controls had similar rates of pregnancy, mean number of pregnancies per woman and age at first pregnancy [31]. After 11.5 years of follow-up in 173 women with bulimia nervosa, $75 \%$ had been pregnant at least once and only $2 \%$ reported that they were unable to conceive [32].

\section{Effects on treatment for infertility}

Under nutrition is not a reliable predictor of conception among infertile women. In 244 cycles of GnRH treatment for oligoamenorrhoea in 48 women, pregnancy rates were not affected by patients' weight or weight loss [33]. With assisted reproduction (ART) treatment, BMI was $<20 \mathrm{~kg} / \mathrm{m} 2$ in $22 \%$ of 398 French women: the delivery rates per started cycle were $21 \%$ in underweight women and $15 \%$ in those with BMI 20 $25 \mathrm{~kg} / \mathrm{m} 2$ [34]. Among 2860 Norwegian women having ART, BMI was $<18.5 \mathrm{~kg} / \mathrm{m} 2$ in $3 \%$; the live birth rates per started cycle were $21 \%$, both in underweight women and in those with BMI $18.5-25 \mathrm{~kg} / \mathrm{m} 2$ [35].

\section{Effects on pregnancy}

Women with a history of being anorexic may have more abortions: $27 \%$ in a cohort of 66 anorexics versus 13\% in a control group [31]. In contrast, a larger follow-up study of 246 women with either anorexia or bulimia reported that 54 women had 82 pregnancies of which 46 (56\%) were live births, $25(31 \%)$ were therapeutic abortions and only $11(13 \%)$ were spontaneous abortions [36].

During pregnancy, women with eating disorders have higher rates of hyperemesis gravidarum, anaemia, impaired weight gain and compromised intrauterine fetal growth [23,37]. Premature delivery is more likely in underweight women. A case control study found that BMI $<20 \mathrm{~kg} / \mathrm{m} 2$ was associated with a four-fold higher likelihood of pre-term labour (OR=3.96, 95\% CI=2.617.09) after adjusting for other known factors [38]. Rates of cesarean delivery, post-natal complications and post-partum depression are higher among mothers with anorexia nervosa [31,39]. Under nutrition is associated with low birth weight (3233g compared with 3516g for normal controls) [37].

Factors associated with premature delivery [38]. OR, odds ratio; $\mathrm{CI}$, confidence interval; body mass index $\mathrm{Kg} / \mathrm{m} 2$ (standing at work $>2 \mathrm{~h} /$ day, stress score: arbitrary scale.

Among women with eating disorders, postponement of conception until remission is recommended because of the impact of low nutrition, but all pregnant women with past or current eating disorders should be viewed as being at high risk and should be monitored closely both during and after pregnancy to ensure optimal maternal and fetal outcomes [35].

\section{Conclusion}

While deprivation and under nutrition are major causes of disease and death in developing countries, eating disorders is more likely to interfere with reproduction in developed countries. Because preservation of female energy expenditure for reproduction is essential, appetite and the reproductive axis are closely linked to nutritional status. As a safeguard against untimely reproduction due to under nutrition, ovarian activity is suppressed in women with eating disorders and 
exercise amenorrhoea through pathways in the hindbrain. It is the balance between energy consumption and utilization that is crucial more than the body fat mass, thus recovery of ovulation may occur after a small percentage gain in weight [36-121].

The combined prevalence of bulimia nervosa and anorexia nervosa is approximately 5\% among women of reproductive age, and the likelihood of cure is higher with bulimia nervosa. Both disorders suppress ovulation in severely affected women and account for up to $60 \%$ of women with anovulatory infertility. Pregnancy among underweight women increases the risk of premature labour.

\section{References}

1. Bekele F (1998) Malnutrition: the 'silent' emergency. In Africa Recovery 11(3): 3.

2. Martin GB, Rodger J and Blache D (2004) Nutritional and environmental effects on reproduction in small ruminants. Reprod Fertil Dev 16(4): 491-501.

3. Wade GN, Jones JE (2004) Neuroendocrinology of nutritional infertility. Am J Physiol Regul Integr Comp Physiol 287: R12772-R1296.

4. Bronson FH (1989) Mammalian Reproductive Biology. University of Chicago Press, Chicago, USA.

5. Laughlin GA, Dominguez CE, Yen SS (1998) Nutritional and endocrinemetabolic aberrations in women with functional hypothalamic amenorrhea. J Clin Endocrinol Metab 83(1): 25-32.

6. Frisch RE, McArthur JW (1974) Menstrual cycles: fatness as a determinant of minimum weight for height necessary for their maintenance or onset. Science 185(4155): 949-951.

7. Frisch RE (1987) Body fat, menarche, fitness and fertility. Hum Reprod 2(6): 521-533.

8. Loucks AB (2003) Energy availability, not body fatness, regulates reproductive function in women. Exerc Sport Sci Rev 31(3): 144-148.

9. Downing JA, Joss J, Scaramuzzi RJ (1995) Ovulation rate and the concentrations of gonadotrophins and metabolic hormones in ewes infused with glucose during the late luteal phase of the oestrous cycle. J Endocrinol 146(3): 403-410.

10. Murahashi K, Bucholtz DC, Nagatani S, Tsukahara S, Tsukamura H, et al. (1996) Suppression of luteinizing hormone pulses by restriction of glucose availability is mediated by sensors in the brain stem. Endocrinology 137(4): 1171-1176.

11. Ohkura S, Tanaka T, Nagatani S, Bucholtz DC, Tsukamura H, et al. (2000) Central, but not peripheral, glucose-sensing mechanisms mediate glucoprivic suppression of pulsatile luteinizing hormone secretion in the sheep. Endocrinology 141(12): 4472-4480.

12. Clarke IJ, Henry BA (1999) Leptin and reproduction. Rev Reprod 4(1): 48-55.

13. Foster DL, Nagatani S (1999) Physiological perspectives on leptin as a regulator of reproduction: role in timing puberty. Biol Reprod 60(2): 205-215.

14. Sawchenko PE, Swanson LW, Grzanna R, Howe PR, Bloom SR, etal. (1985) Colocalization of neuropeptide $\mathrm{Y}$ nimmunoreactivity in brainstem catecholaminergic neurons that project to the paraventricular nucleus of the hypothalamus. J Comp Neurol 241(12): 138-153.

15. Li AJ, Ritter S (2004) Glucoprivation increases expression of neuropeptide $\mathrm{Y}$ mRNA in hindbrain neurons that innervate the hypothalamus. Eur J Neurosci 19(8): 2147-2154.
16. Welt CK, Chan JL, Bullen J, Murphy R, Smith P, et al. (2004) Recombinant human leptin in women with hypothalamic amenorrhea. N Engl J Med 351: 987-997.

17. Schneider JE (2004) Energy balance and reproduction. Physiol Behav 81(2): 289-317.

18. Parr RA (1992) Nutrition-progesterone interactions during early pregnancy in sheep. Reprod Fertil Dev 4(3): 297-300.

19. Bloomfield FH, Oliver MH, Hawkins P, Campbell M, Phillips DJ, et al. (2003) A periconceptional nutritional origin for noninfectious preterm birth. Science 300(5619): 606.

20. Barker DJP (2001) Fetal Origins of Cardiovascular and Lung Disease. ( $1^{\text {st }}$ edn), Decker, New York, USA.

21. Gluckman PD, Hanson MA (2004) Living with the past: evolution, development, and patterns of disease. Science 305(5691): 1733-1736.

22. Elias SG, van Noord PAH, Peeters PHM, den Tonkelaar I, Grobbee DE (2005) Childhood exposure to the 1944-1945 Dutch famine and subsequent female reproductive function. Hum Reprod 20(9): 24832488.

23. Becker AE, Grinspoon SK, Klibanski A, Herzog DB (1999) Eating disorders. N Engl J Med 340: 1092-1098.

24. Stewart D, Robinson GE, Goldbloom DS, Wright C (1990) Infertility and eating disorders. Am J Obstet Gynecol 163(4 Pt 1): 1196-1199.

25. Herzog DB, Dorer DJ, Keel PK, Selwyn SE, Ekeblad ER, et al. (1999) Recovery and relapse in anorexia and bulimia nervosa: a 7.5-year follow-up study. J Am Acad Child Adolesc Psychiatry 38(7): 829-837.

26. Watson TL, Andersen AE (2003) A critical examination of the amenorrhea and weight criteria for diagnosing anorexia nervosa. Acta Psychiatr Scand 108(3): 175-182.

27. Miller KK, Grinspoon SK, Ciampa J, Hier J, Herzog D, et al. (2005) Medical findings in outpatients with anorexia nervosa. Arch Intern Med 165(5): 561-566.

28. Rome ES (2003) Eating disorders. Obstet Gynecol Clin North Am 30: 353-377.

29. Falk JR, Halmi KA (1982) Amenorrhea in anorexia nervosa: examination of the critical body weight hypothesis. Biol Psychiatry 17(7): 799-806.

30. Finfgeld DL (2002) Anorexia nervosa: analysis of long-term outcomes and clinical implications. Arch Psychiatr Nurs 16(4): 176-186.

31. Bulik CM, Sullivan PF, Fear JL, Pickering A, Dawn A, et al. (1999) Fertility and reproduction in women with anorexia nervosa: a controlled study. J Clin Psychiatry 60(2): 130-135.

32. Crow SJ, Thuras P, Keel PK, Mitchell JE (2002) Long-term menstrual and reproductive function in patients with bulimia nervosa. Am J Psychiatry 159(6): 1048-1050.

33. Braat DD, Schoemaker R, Schoemaker J (1991) Life table analysis of fecundity in intravenously gonadotropin-releasing hormone-treated patients with normogonadotropic and hypogonadotropic amenorrhea. Fertil Steril 55(2): 266-271.

34. Wittemer C, Ohl J, Bailly M, Bettahar-Lebugle K, Nisand I (2000) Does body mass index of infertile women have an impact on IVF procedure and outcome? J Assist Reprod Genet 17(10): 547-552.

35. Fedorcsak P, Dale PO, Storeng R, Ertzeid G, Bjercke S, et al. (2004) Impact of overweight and underweight on assisted reproduction treatment. Hum Reprod 19(11): 2523-2528.

36. Blais MA, Becker AE, Burwell RA, Flores AT, Nussbaum KM, et al. (2000) Pregnancy: outcome and impact on symptomatology in a cohort of eating-disordered women. Int J Eat Disord 27(2): 140-149. 
37. Kouba S, Hallstrom T, Lindholm C, Hirschberg AL (2005) Pregnancy and neonatal outcomes in women with eating disorders. Obstet Gynecol 105(2): 255-260.

38. Moutquin JM (2003) Socio-economic and psychosocial factors in the management and prevention of preterm labour. BJOG 110( Suppl 20): 56-60.

39. Franko DL, Blais MA, Becker AE, Delinsky SS, Greenwood DN, et al. (2001) Pregnancy complications and neonatal outcomes in women with eating disorders. Am J Psychiatry 158(9): 1461-1466.

40. Ahima RS, Flier JS (2000) Adipose tissue as an endocrine organ. Trends Endocrinol Metab 11(8) : 327-332.

41. Andreasen KR, Andersen ML, Schantz AL (2004) Obesity and pregnancy. Acta Obstet Gynecol Scand 83: 1022-1029.

42. Anonymous (1998) Executive summary of the clinical guidelines on the identification, evaluation, and treatment of overweight and obesity in adults. Arch Intern Med 158: 1855-1867.

43. Anonymous (2003) Global Strategy for Infant and Young Child Feeding World Health Organization, Geneva, Switzerland, pp. 1-37.

44. Baeten JM, Bukusi EA and Lambe M (2001) Pregnancy complications and outcomes among overweight and obese nulliparous women. Am J Public Health 91(3): 436-440.

45. Bahamondes L, Del CastilloS, Tabares G, Arce XE, Perrotti M, et al. (2001) Comparison of weight increase in users of depot-medroxyprogesterone acetate and copper IUD up to 5 years. Contraception 64: 223-225.

46. Bellver J, Rossal LP, Bosch E, Zuniga A, Corona JT, et al. (2003) Obesity and the risk of spontaneous abortion after oocyte donation. Fertil Steril 79(5): 1136-1140.

47. Brache V, Faundes A, Alvarez F, Cochon L (2002) Non-menstrual events during use of implantable contraceptives for women: data from clinical trials. Contraception 65(1): 63-74.

48. Cedergren MI (2004) Maternal morbid obesity and the risk of adverse pregnancy outcome. Obstet Gynecol 103(2): 219-224.

49. Chi IC, Mumford SD, Laufe LE (1980) Technical failures in tubal ring sterilzation: incidence, perceived reasons, outcome and risk factors. Am J Obstet Gynecol 138(3): 307-312.

50. Clark MK, Dhillon JS, Sowers M, Nichols S (2005) Weight, fat mass and central distribution of fat increase when women use depotmedroxyprogesterone acetate for contraception. Int J Obes 29(10) 1252-1258.

51. Cnattingius S, Lambe M (2002) Trends in smoking and overweight during pregnancy: prevalence, risks of pregnancy complications, and adverse pregnancy outcomes. Semin Perinatol 26(4): 286-295.

52. Colli E, Tong D, Penhallegon R, Parazzini F (1999) Reasons for contraception discontinuation in women 20-39 years old in New Zealand. Contraception 59(4): 227-231.

53. Crosignani PG, Ragni G, Parazzini F, Wyssling H, Lombroso GC, et al. (1994) Anthropometric indicators and response to gonadotrophin for ovulation induction. Hum Reprod 9(3): 420-423.

54. Crosignani PG, Colombo M, Vegetti W, Somigliana E, Gessati A, et al. (2003) Overweight and obese anovulatory patients with polycystic ovaries: parallel improvements in anthropometric indices, ovarian physiology and fertility rate induced by diet. Hum Reprod 18(9): 19281932.

55. Dusterberg B, Brill K (1990) Clinical experience with a low-dose oral contraceptive containing gestodene. Adv Contracept 6: 37-50.

56. Eriksson J, Forsen T, Toumilehto J, Osmond C, Barker D (2001) Size at birth, childhood growth and obesity in adult life. Int J Obes Relat Metab Disord 25(5): 735-740.
57. Fagerberg B, Bondjers L, Nilsson P (2004) Low birth weight in combination with catch-up growth predicts the occurrence of the metabolic syndrome in men at late middle age: the atherosclerosis and insulin resistance study. J Intern Med 256: 254-259.

58. Fedorcsak P, Storeng R, Dale PO, Tanbo T, Abyholm T (2000) Obesity is a risk factor for early pregnancy loss after IVF or ICSI. Acta Obstet Gynecol Scand 79(1): 43-48.

59. Fedorcsak P, Dale PO, Storeng R, Tanbo T, Abyholm T (2001) The impact of obesity and insulin resistance on the outcome of IVF or ICSI in women with polycystic ovarian syndrome. Hum Reprod 16(6): 10861091.

60. Forsvaret (2004) BMI-Statistik.

61. Gale SM, Castrancone D, Mantzoros CS (2004) Energy homeostasis, obesity and eating disorders; recent advances in endocrinology. J Nutr 134(2): 295-298.

62. Gallo MF, Grimes DA, Schultz KF, Helmerhorst FM (2004) Combination estroegn-progestin contraceptives and body weight. Systematic review of randomized controlled trials. Obstet Gynecol 103(2): 359-373.

63. Gallo MF, Grimes DA, Schulz KF, Helmerhorst FM (2003) Combination contraceptives: effects on weight. The Cochrane Database of Systematic Reviews 2, John Wiley \& Sons, Chichester, UK.

64. Glasier A (2002) Implantable contraceptives for women: effectiveness, discontinuation rates, return of fertility and outcome of pregnancies. Contraception 65(1): 29-37.

65. Gupta S (2000) Weight gain on the combined pill B is it real? Hum Reprod Update 6(5): 427-431.

66. Haddock CK, Poston WSC, Dill PL, Foreyt JP, Ericsson M (2002) Pharmacotherapy for obesity: a quantitative analysis of four decades of published randomized clinical trials. Int J Obes Relat Metab Disord 26(3): 262-273.

67. Hamilton-Fairley D, Kiddy D, Watson H, Paterson C, Franks S (1992) Association of moderate obesity with a poor pregnancy outcome in women with polycystic ovary syndrome treated with low dose gonadotrophin. Br J Obstet Gynaecol 99(2): 128-131.

68. Hassan DF, Petta CA, Aldrighi JM, Bahamondes L, Perrotti M (2003) Weight variation in a cohort of women using copper IUD for contraception. Contraception 68: 27-30.

69. Heitmann BL (2000) Ten-year trends in overweight and obesity among Danish men and women aged 30-60 years. Int J Obes Relat Metab Disord 24(10): 1347-1352.

70. Heitmann BL, Kaprio J, Harris JR, Rissanen A, Korkeila M, et al. (1997) Are genetic determinants of weight gain modified by leisure-time physical activity? A prospective study of Finnish twins. Am J Clin Nutr 66(3): 672-678.

71. Hendler I, Goldenberg RL, Mercer BM, Iams JD, Meis PJ, et al. (2005) The preterm prediction study: association between maternal body mass index and spontaneous and indicated preterm birth. Am J Obstet Gynecol 192(3): 882-886.

72. Holt VL, Cushing-Haugen KL, Daling J (2002) Body weight and risk of oral contraceptive failure. Obstet Gynecol 99(5 Pt 1): 820-827.

73. Jamieson DJ, Hillis SD, Duerr A, Marchbamks PA, Costello C, et al. (2000) Complications of interval laparoscopic tubal sterilization: findings from the United States collaborative review of sterilization. Obstet Gynecol 96(6): 997-1002.

74. Jensen H, Agger AO, Rasmussen KL (1999) The influence of prepregnancy body mass index on labor complications. Acta Obstet Gynecol Scand 78(9): 799-802.

75. Junien C, Gallou-Kabani C, Vige A, Gross MS (2005) Nutritional epigenomics of metabolic syndrome. Med Sci (Paris) 21(4): 396-404. 
76. Kershaw EE, Flier JS (2004) Adipose tissue as an endocrine organ. J Clin Endocrinol Metab 89(6): 2548-2556.

77. Kramer MS, Morin I, Yang H, Platt RW, Usher R, et al. (2002) Why are babies getting bigger? Temporal trends in fetal growth and its determinants. J Pediatr 141(4): 538-542.

78. Larsson G, Blohm F, Sundell G, Andersch B, Milson I (1997) A longitudinal study of birth control and pregnancy outcome among women in a Swedish population. Contraception 56(1): 9-16.

79. Lashen H, Fear K, Sturdee DW (2004) Obesity is associated with increased risk of first trimester and recurrent miscarriage: matched case-control study. Hum Reprod 19(7): 1644-1646.

80. Loos RJ, Beunen G, Fagard R, Derom C, Vlietinck R (2001) Birth weight and body composition in young adult men - a prospective twin study. Int J Obes Relat Metab Disord 25(10): 1537-1545.

81. Loos RJ, Beunen G, Fagard R, Derom C, Vlietinck R (2002) Birth weight and body composition in young women: a prospective twin study. Am J Clin Nutr 75(4): 676-682.

82. Neel JV (1962) A 'thrifty' genotype rendered detrimental by 'progress'. Am J Hum Genet 14: 353-362.

83. Nightingale AL, Lawrenson RA, Simpson EL, Williams TJ, Macrae KD, et al. (2000) The effects of age, body mass index, smoking and general health on the risk of venous thromboembolism in users of combined oral contraceptives. Eur J Contracept Reprod Health Care 5(4): 265274.

84. Norman RJ (2004) Editorial: metformin-comparison with other therapies in ovulation induction in polycystic ovary syndrome. J Clin Endocrinol Metab 89(10): 4974-4800.

85. Norman RJ, Noakes M, Wu R, Davies MJ, Moran L, et al. (2004) Improving reproductive performance in overweight/obese women with effective weight management. Hum Reprod Update 10(3): 267-280.

86. Nuthalampaty FS, Rouse DJ (2004) The impact of obesity on obstetrical practice and outcome. Clin Obstet Gynecol 47(4): 898-913.

87. Oddens BJ (1999) Women's satisfaction with birth control: a population survey of physical and psychological effects of oral contraceptives, intrauterine devices, condoms, natural family planning and sterilization among 1466 women. Contraception 59(5): 277-286

88. Oddens BJ, Visser AP, Vemer HM, Everaerd WT and Lehert P (1994) Contraceptive use and attitudes in Great Britain. Contraception 49(1): 73-86.

89. Ong KK, Preece MA, Emmett PM, Ahmed ML, Dunger DB, et al. (2002) Size at birth and early childhood growth in relation to maternal smoking, parity and infant breast-feeding: longitudinal birth cohort study and analysis. Pediatr Res 52(6): 863-867.

90. Ong KK, Petry CJ, Emmett PM, Sandhu MS, Kiess W, et al. (2004) Insulin sensitivity and secretion in normal children related to size at birth, postnatal growth, and plasma insulin-like growth factor-I levels. Diabetologia 47(6): 1064-1070.

91. Pasquali R, Petrusi C, Gerghini S, Cacciari M, Gambineri A (2003) Obesity and reproductive disorders in women. Hum Reprod Update 9(4): 359-372.

92. Pearson S, Olsen LW, Hansen B, Sørensen TIA (2005) Stigning I overvægt og fedme blandt Københavnske skolebørn I perioden 1947 2003. Danish Med 167(02): 158-162.

93. Pinhas-Hamiel O, Dolan LM, Daniels SR, Standiford D, Khoury PR, et al. (1996) Increased incidence of non-insulin-dependent diabetes mellitus among adolescents. J Pediatr 128(5 Pt 1): 608-615.

94. Pratt WR, Bachrach CA (1987) What do women use when they stop using the pill? Fam Plann Perspect 19(6): 257-266.
95. Reilly JJ, Armstrong J, Dorosty AR, Emmett PM, Ness A, et al. (2005) Avon early life risk factors for obesity in childhood: cohort study. BM] 330: 1357-1359.

96. Rich-Edwards JW, Goldman MB, Uett WC, Hunter DJ, Stampfer MJ, et al. (1994) Adolescent body mass index and infertility caused by ovulatory disorder. Am J Obstet Gynecol 171(1): 171-177.

97. Richelsen B, Astrup A, Hansen GL, Hansen HS, Heitmann B, et al. (2002) The Danish Obesity Epidemic. Draft for prevention efforts. A report from the Danish Food Agency (in Danish). pp. 1-131.

98. Ros HS, Cnattingius S and Lipworth L (1998) Comparison of risk factors for preeclampsia and gestational hypertension in a population-based cohort study. Am J Epidemiol 147(11): 1062-1070.

99. Roth D, Grazi RV, Lobel SM (2003) Extremes of body mass index do not affect first-trimester pregnancy outcome in patients with infertility. Am J Obstet Gynecol 188(5): 1169-1170.

100. Schneider JE and Wade GN (1990) Effects of diet and body fat content on cold-induced anestrus in Syrian hamsters. Am J Physiol 259(6 Pt 2): R1198-R1204.

101. Sebire NJ, Jolly M, Harris JP, Wadsworth J, Joffe M, et al. (2001) Maternal obesity and pregnancy outcome: a study of 287213 pregnancies in London. Int J Obes Relat Metab Disord 25(8): 11751182.

102. Sermer M, Naylor CD, Gare DJ, Kenshole AB, Ritchie JW, et al. (1995) Impact of increasing carbohydrate intolerance on maternalfetal outcomes in 3637 women without gestational diabetes. The Toronto Tri-Hospital Gestational Diabetes Project. Am J Obstet Gynecol 173(1): 146-156.

103. Sivin I (1983) Clinical effects of Norplant subdermal implants for contraception. In Mishell DR (Ed.), Long-Acting Steroid Contraception. Advances in Human Fertility and Reproductive Endocrinology, vol. 2. Raven Press, New York, USA, pp. 89-116.

104. Sonne-Holm S, Sørensen TIA, Jensen G, Schnohr P (1980) Influence of fatness, intelligence, education and sociodemographic factors on response rate in a health survey. J Epidemiol Community Health 43(4): 369-374.

105. Sorensen HT, Sabroe S, Gillman M, Rothman KJ, Madsen KM, et al. (1997) Continued increase in prevalence of obesity in Danish young men. Int J Obes Relat Metab Disord 21(8): 712-714.

106. Stunkard AJ, Sørensen TIA (1993) Obesity and socioeconomic status-a complex relation. N Engl J Med 329(14): 1036-1037.

107. Surkan PJ, Hsieh CC, Joansson ALV, Dickman RW, Cnattingius S (2004) Reasons for increasing trends in large for gestational age births. Obstet Gynecol 104(4): 720-726.

108. Taneepanichskul S, Reinprayoon D, Khaosadad P (1998) Comparative study of weight change between long-term DMPA and IUD acceptors. Contraception 58(3): 149-151.

109. Teasdale TW, Sørensen TIA, Stunkard AJ (1990) Genetic and early environmental components in social-demographic influences on adult body fatness. BMJ 300(6740): 1615-1618.

110. Valdez R, Athens MA, Thompson GH, Bradshaw BS, Stern MP (1994) Birth weight and adult health outcomes in a biethnic population in the USA. Diabetologia 37(6): 624-631.

111. Vessey MP, Lawess M, Yeates D, McPherson K (1985) Progestogen-only oral contraception. Findings in a large prospective study with special reference to effectivenss. J Fam Plann 10(4): 117121.

112. Wallace J, Bourke D, Da Silva P, Aitken R (2001) Nutrient partitioning during adolescent pregnancy. Reproduction 122(3): 347357. 
113. Wang JX, Davies M, Norman RJ (2000) Body mass and the probability of pregnancy during assisted reproduction treatment: retrospective study. BMJ 321(7272): 1320-1321.

114. Wang JX, Davies MJ, Norman RJ (2001) Polycystic ovarian syndrome and the risk of spontaneous abortion following assisted reproductive technology treatment. Hum Reprod 16(12): 2606-2609.

115. Wang JX, Davies MJ, Norman RJ (2002) Obesity increases the risk of spontaneous abortion during infertility treatment. Obes Res 10(6): 551-554

116. Weisberg SP, McCann D, Desai M, Rosenbaum M, Leibel RL, et al. (2003) AW obesity is associated with macrophage accumulation in adipose tissue. J Clin Invest 112(12): 1796-1808.

117. Wellen KE, Hotamisligil GS (2003) Obesity-induced inflammatory changes in adipose tissue. J Clin Invest 112(12): 17851788.
118. Westhoff C (2003) Depot-medroxyprogesterone acetate injection (Depoprovera): a highly effective contraceptive option with proven long-term safety. Contraception 68(2): 75-87.

119. World Health Organisation (1997) Obesity: Preventing and Managing the Global Epidemic. Report of WHO Consultation on Obesity, Geneva, Switzerland.

120. World Health Organisation (2004) Medical Eligibility for Contraceptive Use. ( $3^{\text {rd }}$ edn), WHO, Geneva, Switezland.

121. Zieman M, Guillebaud J, Weisberg E, Shangold GA, Fisher AC, et al. (2002) Contraceptive efficacy and cycle control with the Orth Evra TM/Evra TM transdermal system: the analysis of pooled data. Fertil Steril 77(2 suppl 1): S13-S18.

Your next submission with Juniper Publishers will reach you the below assets

- Quality Editorial service

- Swift Peer Review

- Reprints availability

- E-prints Service

- Manuscript Podcast for convenient understanding

- Global attainment for your research

- Manuscript accessibility in different formats

(Pdf, E-pub, Full Text, Audio)

- Unceasing customer service

Track the below URL for one-step submission https://juniperpublishers.com/online-submission.php 